\title{
SYNTHESIS, MOLECULAR DOCKING AND BIOLOGICAL EVALUATION OF SOME NOVEL N-CARBAMOYL PYRAZOLINES AS POTENT ANTI-INFLAMMATORY, ANTIOXIDANT AND ANTIDIABETIC AGENTS
}

\author{
N.A. Peerzade ${ }^{1, *}$, S.Y. Jadhav ${ }^{2}$ and R.B. Bhosale ${ }^{1}$ \\ ${ }^{1}$ School of Chemical Sciences, PAH Solapur University, Solapur-Pune National Highway, Kegaon, \\ Solapur, 413522, (Maharashtra) India \\ ${ }^{2}$ Department of Chemistry, DBF Dayanand College of Arts and Science, Solapur, 413002 \\ (Maharashtra) India \\ *E-mail: nargispeerzade111@gmail.com
}

\begin{abstract}
The present study was carried out to synthesize a series of some Novel N-carbamoyl pyrazoline derivatives, their docking studies and study their biological activities, in vitro antiinflammatory, antioxidant and antidiabetic activities. Title compounds were synthesized by the reaction of pyrazole based chalcones and semicarbazide in the presence of $\mathrm{NaOH}$. The pyrazole chalcones in turn were synthesized by condensation of pyrazole aldehyde with various substituted acetophenones. Synthesis of pyrazole aldehyde was carried out by vilsmeir Hack formylation of phenyl hydrazones. All synthesized N-carbamoyl pyrazolines were studied for their in vitro anti-inflammatory, antioxidant and antidiabetic activities. A docking study was carried out for antiinflammatory and antidiabetic activity. Some of the synthesized compounds show excellent anti-inflammatory activity in comparison to standard Diclofenac sodium whereas some N-carbamoyl pyrazolines show potent anti-inflammatory activity. On the other hand, the antioxidant study was carried out by studying \% inhibition for 2, 2-diphenyl-1-picrylhydrazyl (DPPH) radical, Nitic Oxide free radical (NO) and Superoxide radical (SOR) in comparison to standard ascorbic acid. Synthesized pyrazolines showed excellent to good antioxidant activity. The antidiabetic activity was carried out by assay of $\alpha$-amylase inhibition using acarbose as standard. All synthesized N-carboamyl pyrazolines showed potent to moderate antidiabetic activity.
\end{abstract}

Keywords: Docking, Antidiabetic, Anti-inflammatory, Antioxidant, Pyrazoline, Chalcone.

(C) RASĀYAN. All rights reserved

\section{INTRODUCTION}

Pyrazolines are important five-member heterocyclic compounds and are found to have potential antiinflammatory $^{1}$, antipyretic ${ }^{2}$, antimicrobial ${ }^{3}$, tranquillizing $^{4}$, anticancer ${ }^{5}$, antihypertensive ${ }^{6}$, antiarrhythmic ${ }^{7}$, antitubercular ${ }^{8}$, antidiabetic ${ }^{9}$, antioxidant ${ }^{10}$ and Anti-Amoebic activity ${ }^{11}$. Inflammation is a reaction of the body to infection or another injury, by showing symptoms like redness, warmth, swelling and pain. ${ }^{12,13}$ Research reveals that a large number of pyrazolines showed excellent anti-inflammatory activity. ${ }^{14,15}$ On the other hand, free radicals are a molecule that bears an unpaired electron; they are very reactive and are capable of generating new radicals. Reactive oxygen species are one of them which possess the ability to bind to cellular structures and show various pathological processes such as aging, inflammation, reoxygenation of ischemic tissues, atherosclerosis, cancer and even Parkinson's disease in men ${ }^{16}$. Antioxidants inhibit the process of oxidation, even at very low concentrations. A variety of substituted pyrazolines has been synthesized to date having antioxidant activity hence pyrazoline moiety is having increasing importance as antioxidant agent. ${ }^{17}$ Diabetes mellitus is a very common disease nowadays affecting the citizens of a large number of countries. About $25 \%$ population of the world is suffering from this disease. It occurs due to abnormal carbohydrate metabolism which is responsible for low blood insulin level or insensitivity of target organs to insulin. ${ }^{18}$ Diabetes mellitus can affect badly to various

Rasayan J. Chem., 13(3), 1401-1411(2020)

http://dx.doi.org/10.31788/RJC.2020.1335637

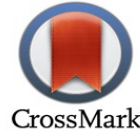


body's systems, like eyes, kidneys, nerves, heart and blood vessels. ${ }^{19,20}$ Hence there is great need nowadays to synthesize new antidiabetic drugs with high potency. Pyrazoline moiety may be useful in designing new antidiabetic drugs. Given the above observations, it would be interesting to synthesize some new molecules having pyrazole moiety to study their biological activities. In this regard, methoxy chalcones would be suited for preparing pyrazoline. In our research work, we have synthesized a novel series of N-carboamyl pyrazoline derivatives from pyrazole based chalcones and studied their biological activities.

\section{Material and Methods}

\section{EXPERIMENTAL}

The title compounds were synthesized by reacting Pyrazole chalcones with phenylhydrazine in the presence of $\mathrm{NaOH}$. Melting points $\left({ }^{\circ} \mathrm{C}\right)$ were determined in the laboratory using the Thiels tube and are incorrect. IR spectra were recorded on FT-IR spectrometer Nicolet IS10 Thermo using the $\mathrm{KBr}$ disc method. ${ }^{1} \mathrm{H}$ NMR spectra were recorded on Bruker $400 \mathrm{MHz}$ spectrometer in $\mathrm{CDCl}_{3}$ as a solvent. ${ }^{13} \mathrm{C}$ NMR spectra were recorded on Brucker $400 \mathrm{MHz}$ spectrometer in $\mathrm{CDCl}_{3}$ as a solvent. All the reagents and solvents were used for an analytical grade. TLC was performed on silica gel coated plates for monitoring the reactions.

\section{Synthesis of Pyrazole based N-Carbamoylpyrazoline Derivatives (6a-j)}

$1 \mathrm{mM}$ of pyrazolechalcone $(\mathbf{5 a}-\mathbf{j})$ was placed in a $100 \mathrm{~mL}$ round bottom flask, $5 \mathrm{~mL}$ ethanol and $20 \%$ $\mathrm{NaOH}$ was added to the reaction mixture. To this solution, $1.0 \mathrm{mM}$ of semicarbazide was added and the reaction mixture was heated at $70-75^{\circ} \mathrm{C}$ for about $4-5 \mathrm{hr}$. Reaction progress was monitored by TLC. After completion of the reaction, the reaction mixture was cooled, poured into crushed ice, the precipitate formed was filtered off and recrystallized from ethanol, affording compounds $\mathbf{6 a - j}$.

\section{5-(4-methoxyphenyl)-1',3'-diphenyl-3,4-dihydro-1'H,2H-[3,4-bipyrazole]-2-carboxamide: 6a} Yield 92\%; M.P: $198-200^{\circ} \mathrm{C}$; $\mathrm{IR}(\mathrm{KBr}): 3458.61\left(\mathrm{C}-\mathrm{NH}_{2}\right.$ stretching), 3065.16(C-H Aromatic stretching ), 2848.10(C-H stretching of $\mathrm{CH}_{2}$ group), $1651.33(\mathrm{C}=\mathrm{O}$ stretching), $1539.90(\mathrm{C}=\mathrm{C}$ stretching), 1258.45 (CO-C stretching) ; ${ }^{1} \mathrm{HNMR}: 3.10$ (dd, $1 \mathrm{H}, \mathrm{J}=4 \mathrm{~Hz} \mathrm{H}$-of pyrazoline $\left.\mathrm{CH}_{2}\right), 3.91\left(\mathrm{~s}, 3 \mathrm{H}-\mathrm{OCH}_{3}\right), 3.66(1 \mathrm{H}, \mathrm{dd}, \mathrm{J}=$ $12 \mathrm{~Hz}, \mathrm{H}$ of pyrazoline $-\mathrm{CH}), 5.83\left(1 \mathrm{H}, \mathrm{dd}, \mathrm{J}=4 \mathrm{~Hz}, \mathrm{H}\right.$ of pyrazoline $\left.\mathrm{CH}_{2}\right), 6.90-7.85(14 \mathrm{H}, \mathrm{Ar}-\mathrm{H})$; ${ }^{13} \mathrm{CNMR}: \delta 41.63\left(\right.$ Pyrazoline $\left.\mathrm{CH}_{2}\right), 52.54\left(-\mathrm{OCH}_{3}\right), 55.39(\mathrm{CH}-\mathrm{N}), 114.09-133.29(\mathrm{Ar}-\mathrm{C}), 150.09(\mathrm{C}=\mathrm{N}$ of pyrazole), $152.33(\mathrm{C}=\mathrm{N}$ Pyrazoline $), 155.39\left(\mathrm{C}-\mathrm{OCH}_{3}\right), 161.21(\mathrm{C}=\mathrm{O})$

\section{3',5-bis(4-methoxyphenyl)-1'-phenyl-3,4-dihydro-1'H,2H-[3,4-bipyrazole]-2-carboxamide: 6b} Yield:90\%;M.P:210-212 ${ }^{\circ} \mathrm{CIR}(\mathrm{KBr}): 3429.51\left(\mathrm{C}-\mathrm{NH}_{2}\right), 2917.15(\mathrm{Ar}-\mathrm{C}-\mathrm{H}), \quad 1662.09(\mathrm{C}=\mathrm{O}$ stretching), $1591.30\left(\mathrm{C}=\mathrm{C}\right.$ stretching), 1245.17(C-O-C); ${ }^{1} \mathrm{HNMR}: \delta 3.08\left(\mathrm{dd}, 1 \mathrm{H}, \mathrm{J}=4 \mathrm{~Hz}, \mathrm{H}-\mathrm{of}\right.$ pyrazoline $\left.\mathrm{CH}_{2}\right)$, $3.855\left(\mathrm{~s}, 6 \mathrm{H},-\mathrm{OCH}_{3}\right), 3.66(1 \mathrm{H}, \mathrm{dd}, \mathrm{J}=12 \mathrm{~Hz}, \mathrm{H}$-of pyrazoline $\mathrm{CH}), 5.6(\mathrm{bs}-\mathrm{NH} 2), 5.82(1 \mathrm{H}, \mathrm{dd}, \mathrm{J}=4 \mathrm{~Hz}, \mathrm{H}-$ of pyrazoline $\left.\mathrm{CH}_{2}\right), 6.90-7.85(14 \mathrm{H}, \mathrm{Ar}-\mathrm{H}){ }^{13} \mathrm{CNMR}$ : $842.64\left(\right.$ Pyrazoline $\left.\mathrm{CH}_{2}\right), 55.56\left(-\mathrm{OCH}_{3}\right), 55.30(-$ $\left.\mathrm{OCH}_{3}\right), 114.06-139.96(\mathrm{Ar}-\mathrm{C}), 152.38(\mathrm{C}=\mathrm{N}), 159.51\left(\mathrm{C}-\mathrm{OCH}_{3}\right), 161.20(\mathrm{C}=\mathrm{O})$

\section{3'-(4-methoxyphenyl)-1',5-diphenyl-3,4-dihydro-1'H,2H-[3,4'-bipyrazole]-2-carboxamide 6c}

Yield: 90\%;M.P: $200-202^{\circ} \mathrm{C}$ : IR(KBr): $\mathrm{cm}^{-1} 3481.71,3275.80\left(\mathrm{C}-\mathrm{NH}_{2}\right) 2917.15(\mathrm{Ar}-\mathrm{C}-\mathrm{H}), 1669.15(\mathrm{C}=\mathrm{O})$, 1538.24 (C=C), 1240.46(C-O-C); ${ }^{1} \mathrm{HNMR}: \delta 3.11\left(\mathrm{dd}, 1 \mathrm{H}, \mathrm{J}=6 \mathrm{~Hz}\right.$ H-of pyrazoline $\mathrm{CH}_{2}$, ), 3.84(s, 3H, $\left.\mathrm{OCH}_{3}\right), 3.68(1 \mathrm{H}, \mathrm{dd}, \mathrm{J}=12 \mathrm{~Hz}, \mathrm{H}$-of pyrazoline $\mathrm{CH}), 5.41\left(\mathrm{bs}_{-} \mathrm{NH}_{2}\right), 5.85(1 \mathrm{H}, \mathrm{dd}, \mathrm{J}=8 \mathrm{~Hz}$, ) H-of pyrazoline $\mathrm{CH}_{2}$, 6.96-7.86(14H, m) ${ }^{13} \mathrm{CNMR}: 42.49\left(-\mathrm{CH}_{2}\right.$ of pyrazoline $), 52.69(\mathrm{C}-\mathrm{N}), 55.30,\left(-\mathrm{OCH}_{3}\right) 114.07-$ 139.94 (Ar-C), $150.02(\mathrm{C}=\mathrm{N}$ of pyrazole $), 152.54(\mathrm{C}=\mathrm{N}$ of pyrazoline $), 152.54\left(\mathrm{C}-\mathrm{OCH}_{3}\right), 159.54(\mathrm{C}=\mathrm{O})$

\section{5-(2,4-dimethoxyphenyl)-1',3'-diphenyl-3,4-dihydro-1'H,2H-[3,4-bipyrazole]-2-carboxamide: 6d}

Yield 92\%; M.P:208-210 ${ }^{\circ} \mathrm{CIR}(\mathrm{KBr}): \mathrm{cm}^{-1} 3477.18\left(\mathrm{C}-\mathrm{NH}_{2}\right), 2931.10(\mathrm{Ar}-\mathrm{C}-\mathrm{H}), 1666.48(\mathrm{C}=\mathrm{O}), 1574.07$, $1289.79(\mathrm{C}-\mathrm{O}-\mathrm{C}) ;{ }^{1} \mathrm{HNMR}: \delta 3.10\left(\mathrm{dd}, 1 \mathrm{H}, \mathrm{J}=4 \mathrm{~Hz}, \mathrm{H}-\right.$ of pyrazoline $\left.\mathrm{CH}_{2}\right), 3.84\left(\mathrm{~s}, 6 \mathrm{H},-\mathrm{OCH}_{3}\right), 3.66(1 \mathrm{H}$, $\mathrm{dd}, \mathrm{J}=12 \mathrm{~Hz}, \mathrm{H}$-of pyrazoline $\mathrm{CH}), 5.33\left(\mathrm{bs}-\mathrm{NH}_{2}\right), 5.83\left(1 \mathrm{H}, \mathrm{dd}, \mathrm{J}=8 \mathrm{~Hz}, \mathrm{H}\right.$-of pyrazoline $\left.\mathrm{CH}_{2}\right), 6.96-$ 7.86(14H, m) ${ }^{13} \mathrm{CNMR}: 52.67(\mathrm{C}-\mathrm{N}), 55.02\left(-\mathrm{OCH}_{3}\right), 61.09\left(-\mathrm{OCH}_{3}\right), 105.67-129.72(\mathrm{Ar}-\mathrm{C}), 159.75$ $(\mathrm{C}=\mathrm{O})$ 
RASĀYAN J. Chem.

Vol. 13 | No. 3 |1401-1411| July - September | 2020

5-(2,5-dimethoxyphenyl)-1',3'-diphenyl-3,4-dihydro-1'H,2H-[3,4-bipyrazole]-2-carboxamide: 6e Yield 88\%; M.P: $206-208^{\circ} \mathrm{C}$; IR(KBr):3395.64 (N-H stretching), 2917.27 (Ar-C-H strtching), 2848.71 (C-H Stretching of $-\mathrm{CH}_{2}$,group), 1651.33 ( $\mathrm{C}=\mathrm{O}$ stretching), 1621.55 (C=C stretching), 1229.83 (C-O-C stretching) ${ }^{1} \mathrm{HNMR}: \delta 3.09\left(\mathrm{dd}, 1 \mathrm{H}, \mathrm{J}=4 \mathrm{~Hz}, \mathrm{H}\right.$-of pyrazoline $\left.\mathrm{CH}_{2}\right), 3.83\left(\mathrm{~s}, 6 \mathrm{H},-\mathrm{OCH}_{3}\right), 3.67(1 \mathrm{H}, \mathrm{dd}, \mathrm{J}=$ $12 \mathrm{~Hz}, \mathrm{H}$-of pyrazoline $\mathrm{CH}), 5.45(\mathrm{bs}-\mathrm{NH} 2), 5.82\left(1 \mathrm{H}, \mathrm{dd}, \mathrm{J}=8 \mathrm{~Hz}, \mathrm{H}\right.$-of pyrazoline $\left.\mathrm{CH}_{2}\right), 6.96-7.86(14 \mathrm{H}$, $\mathrm{Ar}-\mathrm{H})^{13} \mathrm{CNMR}: \delta \quad 42.58\left(\right.$ Pyrazoline $\left.\mathrm{CH}_{2}\right), 52.69(\mathrm{CH}-\mathrm{N}), 55.29\left(-\mathrm{OCH}_{3}\right), 55.38\left(-\mathrm{OCH}_{3}\right), 114.41-139.90$ $(\mathrm{Ar}-\mathrm{C}), 149.98(\mathrm{C}=\mathrm{N}$ of pyrazole $), 152.43(\mathrm{C}=\mathrm{N}$ Pyrazoline $), 155.24\left(\mathrm{C}-\mathrm{OCH}_{3}\right), 159.68(\mathrm{C}=\mathrm{O})$

\section{5-(3-methoxyphenyl)-3'-(4-mrthoxyphenyl)-1'-phenyl-3,4-dihydro-1'H,2H-[3,4-bipyrazole]-2- carboxamide: $6 f$}

Yield: 84\%;M.P:200-202 ${ }^{\circ} \mathrm{CIR}(\mathrm{KBr}): \mathrm{cm}^{-1} 3290.51(\mathrm{C}-\mathrm{NH} 2)$, 2918.56 (C-H aromatic stretching) , 2848.80 (C-H stretching of $\mathrm{CH}_{2}$ group), $1651.96(\mathrm{C}=\mathrm{O}), 1607.25(\mathrm{C}=\mathrm{C}), 1229.68(\mathrm{C}-\mathrm{O}-\mathrm{C})$; ${ }^{1} \mathrm{HNMR}: \delta 3.10$ (dd, $1 \mathrm{H}, \mathrm{J}=4 \mathrm{~Hz} \mathrm{H}$-of pyrazoline $\mathrm{CH}_{2}$, ) $3.851-3.859\left(\mathrm{~s}, 6 \mathrm{H}-\mathrm{OCH}_{3}\right), 3.67(1 \mathrm{H}, \mathrm{dd}, \mathrm{J}=12 \mathrm{~Hz} \mathrm{H}$-of pyrazoline $\mathrm{CH},), 5.43$ (bs-NH2), 5.825(1H, dd, $\mathrm{J}=8 \mathrm{~Hz}, \mathrm{H}-\mathrm{of}$ pyrazoline $\left.\mathrm{CH}_{2}\right), 6.96-7.86(14 \mathrm{H}, \mathrm{Ar}-\mathrm{H})$; ${ }^{13} \mathrm{CNMR}: 41.62\left(\mathrm{CH}_{2}\right.$ of pyrazoline), $55.41\left(-\mathrm{OCH}_{3}\right), 57.47\left(-\mathrm{OCH}_{3}\right), 123.25-132.51$ (Aromatic $\mathrm{C}$ ), $154.16(\mathrm{C}=\mathrm{N}), 161.55\left(\mathrm{C}-\mathrm{OCH}_{3}\right), 158.88(\mathrm{C}=\mathrm{O})$.

3'-(4-methoxyphenyl)-1'-phenyl-5-(3,4,5-trimethoxyphenyl)-3,4-dihydro-1'H,2H-[3,4'-bipyrazole]2-carboxamide: $6 \mathbf{g}$

Yield:90\%; M.P: $214-216^{\circ} \mathrm{CIR}(\mathrm{KBr}): \mathrm{cm}^{-1} 3285.52$ (Ar-C-H), 2917.63(C-H Aromatic stretching), 2848.62 (C-H stretching of $\mathrm{CH}_{2}$ group), $1651.05(\mathrm{C}=\mathrm{O}), 1621.77(\mathrm{C}=\mathrm{N}), 1028.94(\mathrm{C}-\mathrm{O}-\mathrm{C})$;HNMR: $\delta 3.09(\mathrm{dd}, 1 \mathrm{H}$, $\mathrm{J}=4 \mathrm{~Hz}, \mathrm{H}$-of pyrazoline $\left.\mathrm{CH}_{2}\right), 3.83-3.92\left(\mathrm{~s}, 12 \mathrm{H},-\mathrm{OCH}_{3}\right), 3.66(1 \mathrm{H}, \mathrm{dd}, \mathrm{J}=12 \mathrm{~Hz}, \mathrm{H}$-of pyrazoline $\mathrm{CH}$ ), 5.37(bs-NH2), $5.83\left(1 \mathrm{H}, \mathrm{dd}, \mathrm{J}=4 \mathrm{~Hz}, \mathrm{H}\right.$-of pyrazoline $\left.\mathrm{CH}_{2}\right), 6.96-7.86(13 \mathrm{H}, \mathrm{Ar}-\mathrm{H}) ;{ }^{13} \mathrm{CNMR}: \delta 41.78$ (pyrazoline $\left.-\mathrm{CH}_{2}\right), 55.60\left(-\mathrm{OCH}_{3}\right), 56.29\left(-\mathrm{OCH}_{3}\right), 61.01\left(-\mathrm{OCH}_{3}\right), 123.32-145.292(\mathrm{Ar}-\mathrm{C}), 153.42(\mathrm{C}-$ $=\mathrm{N}$ of pyrazole $), 154.14(\mathrm{C}=\mathrm{N}$ of pyrazoline $), 158.36(\mathrm{C}=\mathrm{O})$

5-(3,4-dimethoxyphenyl)-1',3'-diphenyl-3,4-dihydro-1'H,2H-[3,4-bipyrazole]-2-carboxamide: 6h Yield 92\%;M.P: $208-210^{\circ} \mathrm{C}$; $\mathrm{IR}(\mathrm{KBr}): \mathrm{cm}^{-1} 3458.61\left(\mathrm{C}-\mathrm{NH}_{2}\right.$ stretching), 2848.10(C-H strtching of $\mathrm{CH}_{2}$ group),1651.33 ( $\mathrm{C}=\mathrm{O}$ stretching), $1539.90\left(\mathrm{C}=\mathrm{C}\right.$ stretching) 1258.45 (C-O-C stretching); ${ }^{1} \mathrm{HNMR}$ : $\delta$ $3.08(\mathrm{dd}, 1 \mathrm{H}, \mathrm{J}=4 \mathrm{~Hz}), 3.84-3.86\left(\mathrm{~s}, 6 \mathrm{H},-\mathrm{OCH}_{3}\right), 3.64(1 \mathrm{H}, \mathrm{dd}, \mathrm{J}=12 \mathrm{~Hz}), 5.35(\mathrm{bs}-\mathrm{NH} 2), 5.81(1 \mathrm{H}, \mathrm{dd}$, $\mathrm{J}=4 \mathrm{~Hz}, \mathrm{H}$-of pyrazoline $\left.\mathrm{CH}_{2}\right), 6.90-7.85(14 \mathrm{H}, \mathrm{Ar}-\mathrm{H}) ; ;{ }^{13} \mathrm{CNMR}: 42.24(-\mathrm{CH} 2$ of pyrazoline), 52.77 (C$\mathrm{N}), 55.29(-\mathrm{OCH} 3), 55.38(-\mathrm{OCH} 3), 114.05-140.04(\mathrm{Ar}-\mathrm{C} 0,159.51(\mathrm{C}=\mathrm{O})$

\section{3'-(4-methoxyphenyl)-1'-phenyl-5-(2,3,4-trimethoxyphenyl)-3,4-dihydro-1'H,2H-[3,4'-bipyrazole]-} 2-carboxamide: $6 \mathbf{i}$

Yield 92\%;M.P: $218-220^{\circ} \mathrm{CIR}(\mathrm{KBr}): 2923.99$ (C-H Aromatic strtching), 2852.96 (C-H strtching of $\mathrm{CH}_{2}$ group), $1632.14\left(\mathrm{C}=\mathrm{O}\right.$ strtching), $1499.32\left(\mathrm{C}=\mathrm{C}\right.$ stretching), 1295.59 (C-O-C stretching) ${ }^{1} \mathrm{HNMR}: \delta 3.11$ (dd, $1 \mathrm{H}, \mathrm{J}=4 \mathrm{~Hz}), 3.83-3.92(\mathrm{~s}, 12 \mathrm{H}), 3.66(1 \mathrm{H}, \mathrm{dd}, \mathrm{J}=12 \mathrm{~Hz}), 5.390(\mathrm{bs}-\mathrm{NH} 2), \quad 5.83(1 \mathrm{H}, \mathrm{dd}, \mathrm{J}=4 \mathrm{~Hz})$, 6.83-7.84(11H, m); ${ }^{13} \mathrm{CNMR}: 42.62(-\mathrm{CH} 2$ of pyrazoline), $52.69(\mathrm{C}-\mathrm{N}), 55.30-60.99$ (-OCH3), 114.05$140.04(\operatorname{Ar}-\mathrm{C}), 152.30(\mathrm{C}=\mathrm{N}), 153.32(\mathrm{C}=\mathrm{N}), 155.10(\mathrm{C}-\mathrm{OCH} 3), 159.52(\mathrm{C}=\mathrm{O})$

1',3' 5-triphenyl-3,4-dihydro-1'H,2H[3,4'-bipyrazole]-2-carboxamide: $6 \mathbf{j}$ Yield 92\%;M.P: $198-200^{\circ} \mathrm{C} ; \mathrm{IR}(\mathrm{KBr}): \mathrm{cm}^{-1} 3547.44\left(\mathrm{C}-\mathrm{NH}_{2}\right), 2917.55$ (Aromatic C-H stretching), 1638.22 $(\mathrm{C}=\mathrm{O}), 1510.23(\mathrm{C}=\mathrm{C}), 1291.8(\mathrm{C}-\mathrm{O}-\mathrm{C}){ }^{1}{ }^{1} \mathrm{HNMR}: \delta 3.04\left(\mathrm{dd}, 1 \mathrm{H}, \mathrm{J}=4 \mathrm{~Hz}, \mathrm{H}\right.$-of pyrazoline $\left.\mathrm{CH}_{2}\right)$, $3.855\left(\mathrm{~s}, 6 \mathrm{H},-\mathrm{OCH}_{3}\right), 3.61(1 \mathrm{H}, \mathrm{dd}, \mathrm{J}=12 \mathrm{~Hz}, \mathrm{H}$-of pyrazoline $\mathrm{CH}), 5.56(\mathrm{bs}-\mathrm{NH} 2), 5.77(1 \mathrm{H}, \mathrm{dd}, \mathrm{J}=4 \mathrm{~Hz}, \mathrm{H}-$ of pyrazoline $\left.\mathrm{CH}_{2}\right), 6.90-7.85(15 \mathrm{H}, \mathrm{Ar}-\mathrm{H}),{ }^{13} \mathrm{CNMR}: 42.98\left(-\mathrm{CH}_{2}\right.$ of pyrazoline), $52.67(\mathrm{C}-\mathrm{N}), 114.08-$ $039.94($ AR-C), $152.54(\mathrm{C}=\mathrm{N}$ of pyrazole $), 152.51(\mathrm{C}=\mathrm{N}$ of pyrazoline $), 159.62(\mathrm{C}=\mathrm{O})$

\section{Pharmacology}

In-vitro Anti-inflammatory Activity by Protein Denaturation Method

A mixture of $0.1 \mathrm{~mL}$ of egg albumin (from fresh hen's egg), $1.4 \mathrm{~mL}$ of phosphate buffered saline (PBS, $\mathrm{pH}$ 6.4) and $1 \mathrm{~mL}$ of synthesized N-carbamoyl pyrazoline at $1 \mathrm{mM}$ concentration was incubated at $\left(37^{\circ} \mathrm{c}\right.$ 
RASĀYAN J. Chem.

Vol. 13 | No. 3 |1401-1411| July - September | 2020

$\pm 2)$ in an incubator for $15 \mathrm{~min}$. Then reaction mixture was heated at $70^{\circ} \mathrm{c}$ for $5 \mathrm{~min}$. Similar volume of double-distilled water was used as control. Reaction mixture was cooled; absorbance of reaction mixture and control were measured at $660 \mathrm{~nm}$, vehicle was used as blank. Diclofenac sodium at $1 \mathrm{mM}$ concentration was used as reference drug and treated similarly for determination of absorbance. The $\%$ inhibition of protein denaturation was calculated by using the following formula given below:

$$
\% \text { inhibition }=100 \times(\mathrm{Vt} / \mathrm{Vc}-1)
$$

Where, $\mathrm{Vt}=$ absorbance of test sample, $\mathrm{Vc}=$ absorbance of control

\section{Antioxidant Activity \\ DPPH Radical Scavenging Activity}

$1 \mathrm{ml}$ of $\mathrm{N}$-carbamoyl pyrazoline at $1 \mathrm{mM}$ concentration was mixed with $3.0 \mathrm{~mL}$ DPPH $(0.5 \mathrm{mmol} / \mathrm{L}$ in methanol), the reaction mixture was incubated at $37^{\circ} \mathrm{C}$ for 30 minutes; the absorbance of the reaction mixture was recorded at $517 \mathrm{~nm}$. The percentage of scavenging activity was calculated using the formula,

Percentage of Inhibition $(\%)=\left[\left(\mathrm{A}_{\text {control }}-\mathrm{A}_{\text {sample }}\right) / \mathrm{A}\right.$ control $] \times 100$

Where, $\mathrm{A}_{\text {control }}$ - absorbance of DPPH and $\mathrm{A}_{\text {sample }}$ - absorbance reaction mixture (DPPH with Sample)

\section{NO Scavenging Activity}

$1 \mathrm{~mL}$ of $10 \mathrm{mM}$ sodium nitroprusside dissolved in $0.5 \mathrm{~mL}$ phosphate buffer saline $(\mathrm{pH} 7.4)$ was mixed with $1 \mathrm{~mL}$ of $1 \mathrm{mM} \mathrm{N}$-carbamoyl pyrazoline dissolved in DMSO. The reaction mixture was incubated at $25{ }^{\circ} \mathrm{C}$ for $150 \mathrm{~min}$. After incubation, the reaction mixture was mixed with $1.0 \mathrm{~mL}$ of pre-prepared Griess reagent $[(1.0 \mathrm{~mL}$ sulfanilic acid reagent $(0.33 \%$ in $20 \%$ glacial acetic acid at room temperature for 5 minutes with $1 \mathrm{~mL}$ of naphthyl ethylenediamine dichloride $(0.1 \% \mathrm{w} / \mathrm{v})]$. The mixture was then incubated at room temperature for $30 \mathrm{~min}$ and its absorbance was measured by pouring into a cuvette at $546 \mathrm{~nm}$. The decreasing absorbance indicated a high nitric oxide scavenging activity. The amount of NO radical inhibition was calculated as below:

$$
\% \text { inhibition of } \mathrm{NO} \text { radical }=\left[\left(\mathrm{A}_{0}-\mathrm{A}_{1}\right) / \mathrm{A}_{0}\right] \mathrm{X} 100
$$

Where $\mathrm{A}_{0}$ is the absorbance before reaction and $\mathrm{A}_{1}$ is the absorbance after reaction with Griess reagent.

\section{SOR Scavenging Activity}

$1.0 \mathrm{~mL}$ of N-carbamoyl pyrazoline $(1 \mathrm{mM})$ solution was added to $3.0 \mathrm{~mL}$ of Tris- $\mathrm{HCl}$ buffer $(16 \mathrm{mM}, \mathrm{pH}$ $8.0)$, containing $0.5 \mathrm{~mL}$ of nitrobluetetrazolium (NBT) $(0.3 \mathrm{mM}), 0.5 \mathrm{~mL} \mathrm{NADH}(0.936 \mathrm{mM})$ solution. The reaction was initiated by adding $0.5 \mathrm{~mL}$ phenazine methosulfate (PMS) solution $(0.12 \mathrm{mM})$ to the reaction mixture, the reaction mixture was incubated at $25{ }^{\circ} \mathrm{C}$ for $5 \mathrm{~min}$ and then the absorbance was measured at $560 \mathrm{~nm}$ against a blank sample. Decreased absorbance of the reaction mixture indicated increased superoxide anion scavenging activity.

\section{Antidiabetic Activity Assay of Amylase Inhibition}

$100 \mu \mathrm{L}$ of samples $(1 \mathrm{mM})$ was reacted with $200 \mu \mathrm{L}$ of the $\alpha$-amylase enzyme (Diastase) and $100 \mu \mathrm{L}$ of 2 $\mathrm{mM}$ of phosphate buffer (pH-6.9). The reaction mixture was incubated for 20 minutes. After a 20 -minute incubation, $100 \mu \mathrm{L}$ of $1 \%$ starch solution was added. The same was performed for the controls where 200 $\mu \mathrm{L}$ of the enzyme was replaced by the buffer. After incubation, $500 \mu \mathrm{L}$ of dinitrosalicylic acid reagent was added to both control and test. They were kept in boiling water bath for $5 \mathrm{~min}$. The absorbance was recorded at $540 \mathrm{~nm}$ using spectrophotometer and the percentage inhibition of $\alpha$-amylase enzyme was calculated using the formula:

$$
\% \text { Inhibition }=\left[\mathrm{A}_{\text {Control }}-\mathrm{A}_{\text {Test }} / \mathrm{A}_{\text {Control }}\right] \times 100
$$

Where $\mathrm{A}_{\text {Control }}=$ absorbance of control and $\mathrm{A}_{\text {Test }}=$ Absorbance of test

\section{Molecular Docking}

Molecular docking was performed to predict the molecular mechanism of the developed molecules. Crystal structure of Human COX II (5KIR), while the Crystal structure of the human peroxisome 
RASĀYAN J. Chem.

Vol. 13 | No. 3 |1401-1411| July - September | 2020

proliferator-activated receptor gamma (2PRG) downloaded from the free protein database www.rcsb.org ${ }^{20}$ was utilized for docking analysis. Grip based docking analysis was carried out using biopredicta molecule of Vlife MDS 4.6.

\section{RESULTS AND DISCUSSION}

The pyrazolines were synthesized as outlined in Scheme-1. Pyrazole aldehyde is obtained via vilsmeir Haack reaction by treating acetophenone and phenylhydrazine to give the corresponding hydrazone which on reaction with $\mathrm{DMF} / \mathrm{POCl}_{3}$ gives pyrazole aldehyde (3). The pyrazolechalcones $(\mathbf{5 a} \mathbf{a}-\mathbf{1 j})$ were prepared by reaction of various methoxy substituted acetophenones and pyrazole aldehyde (3) in the presence of $\mathrm{NaOH}$. These chalcones were treated with semicarbazide in the presence of $\mathrm{NaOH}$ and heated for $4-5 \mathrm{hrs}$ to afford pyrazoline derivatives (6a-j). The completion of the reaction was monitored by TLC. All the synthesized pyrazolines were characterized by IR, ${ }^{1} \mathrm{HNMR}$ and ${ }^{13} \mathrm{CNMR}$. The IR spectra of N-carbamoyl pyrazolines shows that the $(>\mathrm{C}=\mathrm{O})$ absorption bands were at $1609-1638 \mathrm{~cm}^{-1}$ and the $(>\mathrm{C}=\mathrm{N}-)$ stretching bands were observed at $1595 \mathrm{~cm}^{-1}$. These values confirm the formation of desired pyrazoline derivatives. In the ${ }^{1} \mathrm{HNMR}$ spectra of pyrazolines, the chiral methine proton appeared at $\sim \delta 3.2-3.3$ and $\sim 5.91-5.95$ as two distinct doublets of a doublet which is a characteristic chemical shift and splitting pattern of pyrazolines.<smiles>[R]c1ccc(C(=O)/C=C/c2cn(-c3ccccc3)nc2-c2ccc([R])cc2)cc1</smiles>

Scheme-1

Reagents and Conditions: a.conc. $\mathrm{H}_{2} \mathrm{SO}_{4}$, b. DMF/POCl $3,80-85^{\circ}$ c, $4-5 \mathrm{Hrs}$, c.5\% $\%$ aOH, EtOH, RT, 24hrs, d. NaOH, $\mathrm{NH}_{2} \mathrm{CONH} . \mathrm{NH}_{2} \cdot \mathrm{HCl} \mathrm{HCl}$, EtOH, Reflux 6-7 hrs

All the synthesized N-carboamylpyrazolines were evaluated for their anti-inflammatory, antioxidant and antidiabetic activities. Results of which have been shown in Table-1.

\section{Anti-inflammatory Activity}

All synthesized compounds were also tested for their anti-inflammatory activity ${ }^{21}$ using diclophenac sodium as standard drug. It can be observed from the results that all N-carbamoyl pyrazolines show good anti-inflammatory activity. Compound $\mathbf{6 h}$ shows maximum anti-inflammatory activity in comparison to the standard. Compounds $\mathbf{6 e}, \mathbf{6 d}, \mathbf{6 g}$ and $\mathbf{6 i}$ have shown potent anti-inflammatory activity. Compounds $\mathbf{6 a}$, $\mathbf{6 b}, \mathbf{6 c}$ and $\mathbf{6 j}$ possess moderate activity whereas $\mathbf{6 c}$ showed the least anti-inflammatory activity in the series.

\section{Antioxidant Activity}

Antioxidant activity of synthesized N-carbamoyl pyrazoline derivatives was studied against reactive oxygen species like DPPH, Nitric oxide and Superoxide radical scavenging activity ${ }^{22}$ using ascorbic acid as a standard antioxidant agent and presented in Table-1. 
RASĀYAN J. Chem.

Vol. 13 | No. 3 |1401-1411| July - September | 2020

Antioxidant activity study reveals that compounds $\mathbf{6 a}, \mathbf{6 d}, \mathbf{6 g}$ and $\mathbf{6 j}$ show excellent antioxidant activity for DPPH radical. Compound $\mathbf{6 f}$ showed maximum inhibition for NO and SOR free radical.

Table-1: Biological Activities of N-Carboamyl Pyrazolines

\begin{tabular}{|c|c|c|c|c|c|}
\hline \multirow[t]{2}{*}{ Compounds } & \multirow{2}{*}{$\begin{array}{c}\text { Anti-inflammatory Activity } \\
\% \text { Inhibition }\end{array}$} & \multicolumn{3}{|c|}{ Antioxidant Activity } & \multirow{2}{*}{$\begin{array}{c}\text { Antioxidant } \\
\text { Activity }\end{array}$} \\
\hline & & DPPH & $\begin{array}{c}\text { Nitric Oxide } \\
\text { Scavenging } \\
\text { Activity }\end{array}$ & $\begin{array}{c}\text { Super Oxide } \\
\text { Scavenging } \\
\text { Activity }\end{array}$ & \\
\hline $6 a$ & 59.79 & 84.07 & 35.93 & 04.87 & 21.73 \\
\hline $6 \mathrm{~b}$ & 67.01 & 07.07 & 31.25 & 82.92 & 54.34 \\
\hline $6 \mathrm{c}$ & 49.48 & 08.84 & 35.93 & 17.07 & 50.00 \\
\hline $6 \mathrm{~d}$ & 78.35 & 83.78 & 06.25 & 25.60 & 50.00 \\
\hline $6 \mathrm{e}$ & 61.85 & 08.84 & 0.6 .25 & 39.02 & 43.47 \\
\hline $6 f$ & 59.39 & 06.19 & 65.62 & 76.82 & 32.60 \\
\hline $6 \mathrm{~g}$ & 76.28 & 83.06 & 53.12 & 78.04 & 26.08 \\
\hline $6 \mathrm{~h}$ & 81.44 & 03.53 & 37.50 & 57.31 & 36.95 \\
\hline $6 \mathrm{i}$ & 70.10 & 27.43 & 20.31 & 54.87 & 43.47 \\
\hline $6 \mathrm{j}$ & 64.94 & 82.43 & 06.25 & 32.92 & 58.69 \\
\hline $\begin{array}{l}\text { Diaclofenac } \\
\text { Sodium }\end{array}$ & 85.56 & -- & -- & -- & -- \\
\hline Ascorbic Acid & & 92.03 & 71.87 & 90.24 & \\
\hline Acarbose & & & & & 76.08 \\
\hline
\end{tabular}

\% Inhibition was calculated by measuring absorbance at $660 \mathrm{~nm}$ for anti-inflammatory activity, $517 \mathrm{~nm}$ for DPPH, $546 \mathrm{nmfor}$ NO., $560 \mathrm{~nm}$ for SOR and 540 $\mathrm{nm}$ for antidiabetic activity.

\section{Antidiabetic Activity}

Antidiabetic activity of synthesized N-carbamoyl pyrazolines was tested by the method using assay of amylase inhibition and \% inhibitions of the compounds were determined as compared to standard acarbose $^{23}$. All the compounds showed excellent inhibition of amylase in comparison to standard acarbose and the results have been shown in Table-1. Compounds $\mathbf{6 j}$ and $\mathbf{6 b}$ are having more potent antidiabetic activity from the series whereas compounds $\mathbf{6 c}, \mathbf{6 d}, \mathbf{6 e}$ and $\mathbf{6 i}$ are showing good antidiabetic activity as compared to standard acarbose.

From the above discussion, it can be noted that all the synthesized N-carboamyl pyrazoline derivatives are having potential biological activities and they can be useful in designing new drugs.

\section{Molecular Docking}

Molecular Docking was utilized to study the mode of action of the synthesized derivatives for antiinflammatory and anti-diabetic activity. Crystal structure of Human COX II (5KIR), while Crystal structure of the human peroxisome proliferator-activated receptor gamma (2PRG) downloaded from the free protein database www.rcsb.org ${ }^{24}$ was utilized for docking analysis. Grip based docking analysis was carried out using biopredicta molecule of Vlife MDS 4.6. ${ }^{25,26}$

\section{Docking Study For Anti-inflammatory Activity}

All synthesized derivatives have shown the same binding mode for anti-inflammatory activity $\mathbf{6 h}$ is the most active molecule showed important binding interactions like hydrogen bond interactions with VAL523, TYR385, aromatic interactions withHIS90, TYR348, TYR385 and hydrophobic interactions with THR206, VAL344, VAL349, LEU352, GLY526, SER530, LEU534. 6e showed hydrogen bond interaction with HIS90 aromatic interaction with TRP387, PHE518 hydrophobic interactions with VAL116, VAL349, LEU352, LEU359, VAL523, ALA527, SER 530. 6d showed hydrogen bond interaction with MET522, aromatic bond interaction with HIS90, TYR348, TYR385, PHE518 and hydrophobic interactions with VAL344, VAL349, LEU352, LEU384, VAL523, GLY526,SER530, LEU534. 6g showed hydrogen bond interactions HIS90,TYR355, aromatic bond interaction with HIS90, 
RASĀYAN J. Chem.

Vol. 13 | No. 3 |1401-1411| July - September | 2020

PHE518and hydrophobic interactions with HIS90, THR94, VAL116, ARG120, VAL349,LEU352SER353, ILE517,PHE518, VAL523, ALA527,SER530, LEU531. 6i showed hydrogen bond interaction with SER530, aromatic bond interactions with HIS90, TYR355 and hydrophobic interactions with LEU93, ARG120, LEU352, SER353, PHE518, VAL523, GLY526, ALA527, PRO528, PHE529, SER530, LEU531.
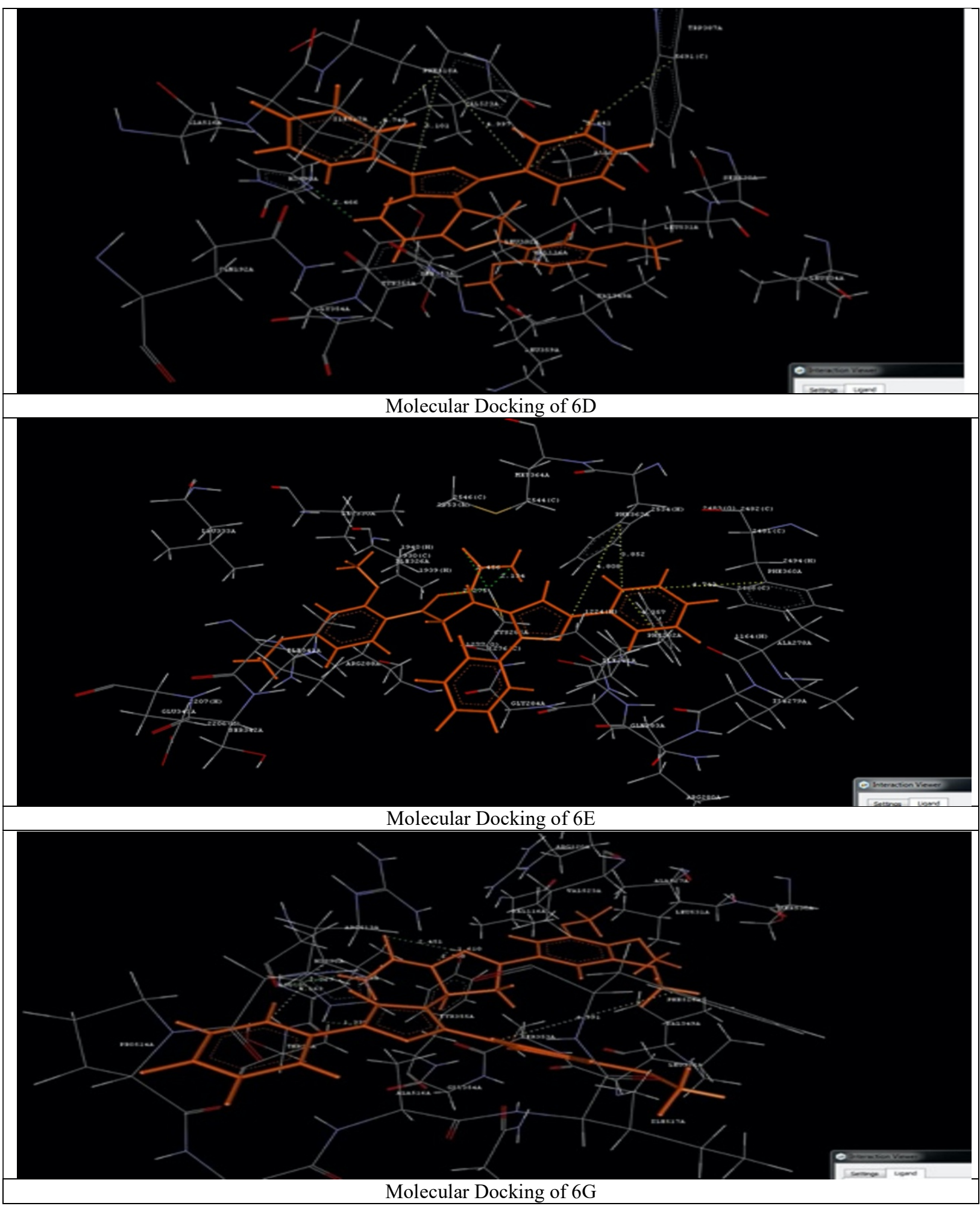

Molecular Docking of 6G 
RASĀYAN J. Chem.

Vol. 13 | No. 3 |1401-1411| July - September | 2020
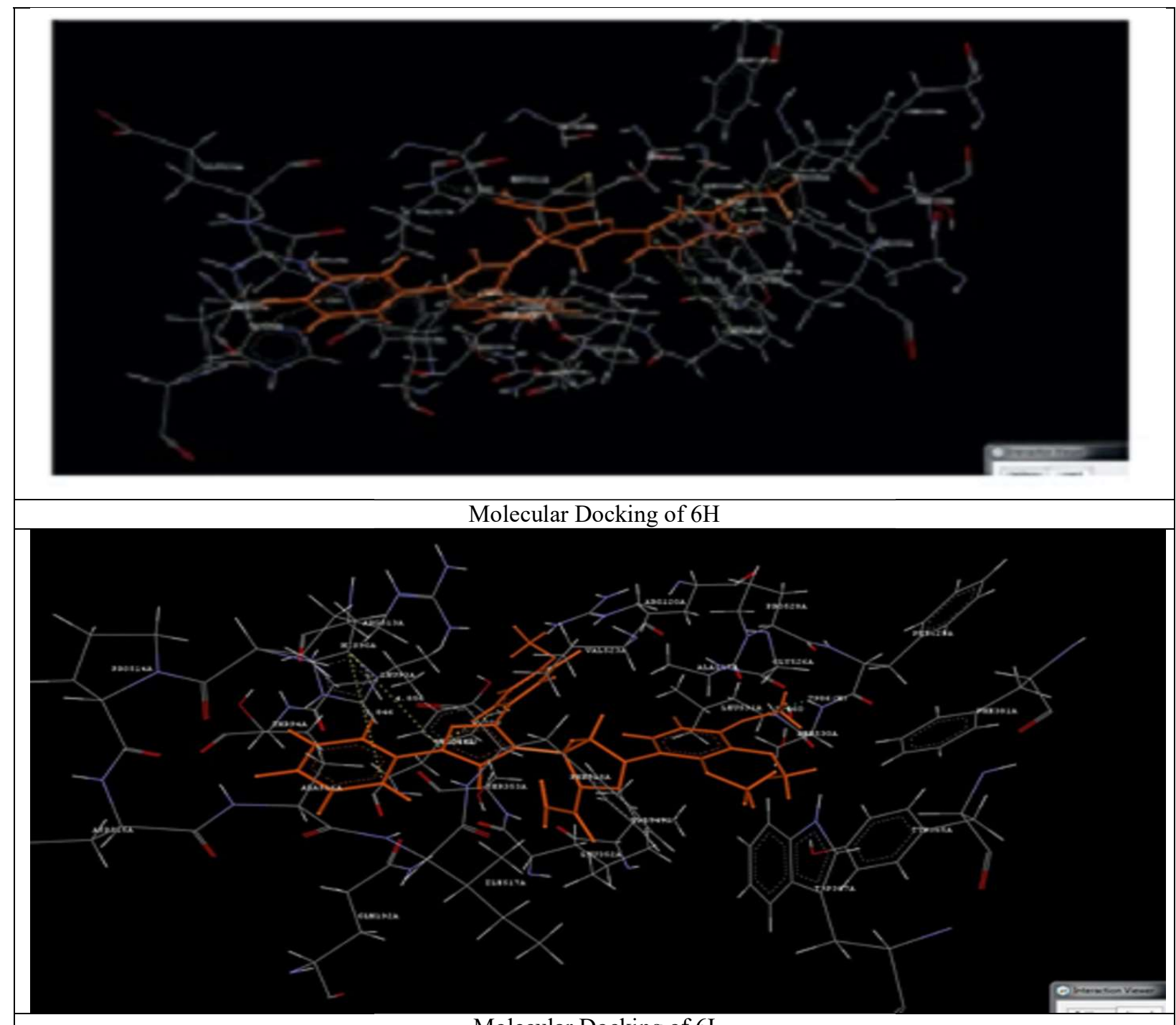

Molecular Docking of 6I

Fig.-1: Molecular Docking For Anti-inflammatory Activity

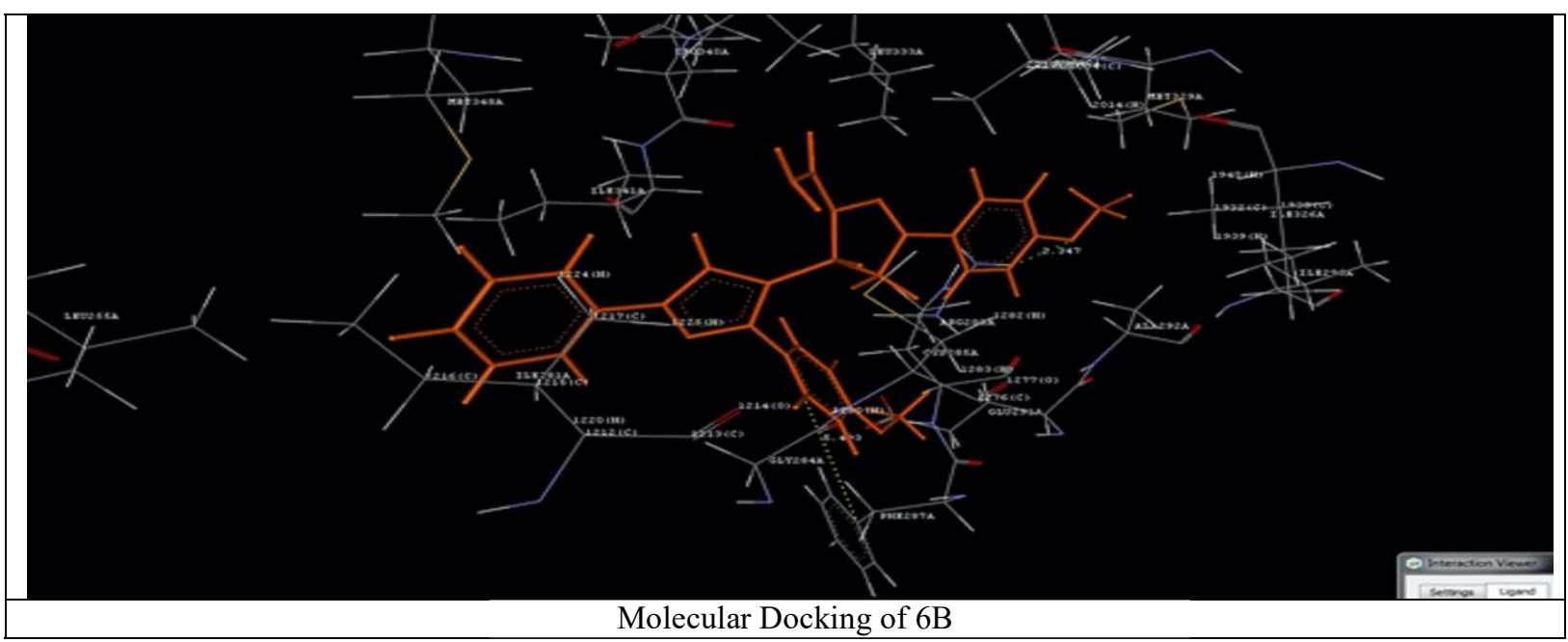


RASĀYAN J. Chem.

Vol. 13 | No. 3 |1401-1411| July - September | 2020

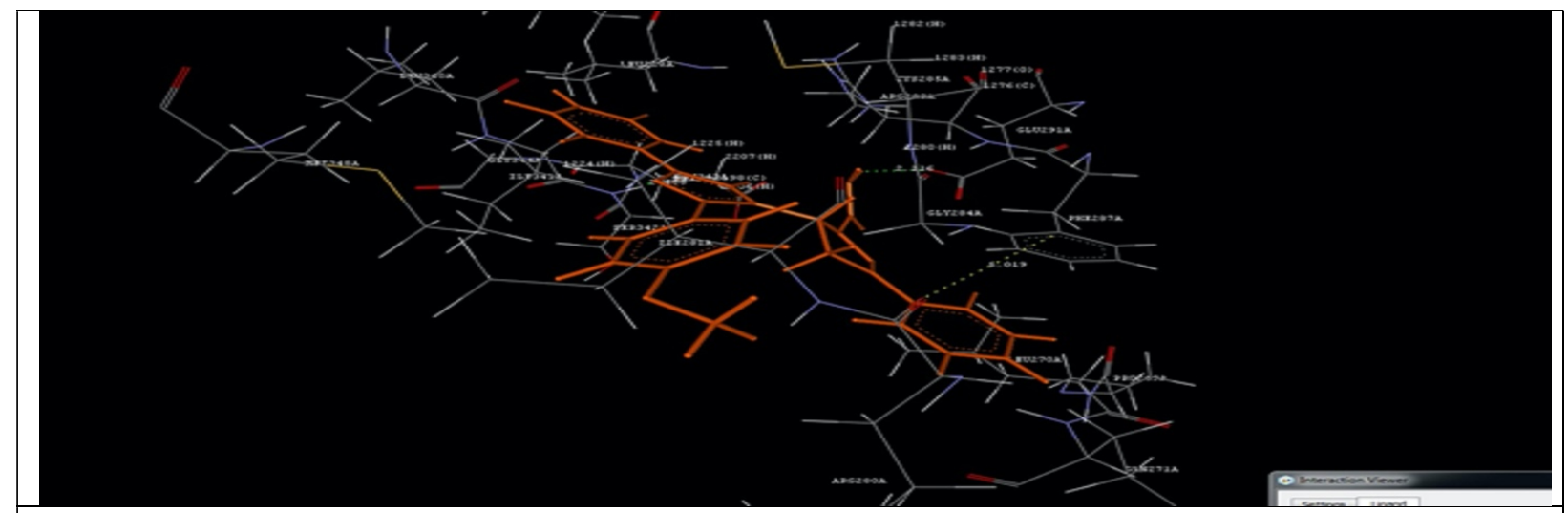

Molecular Docking of 6C

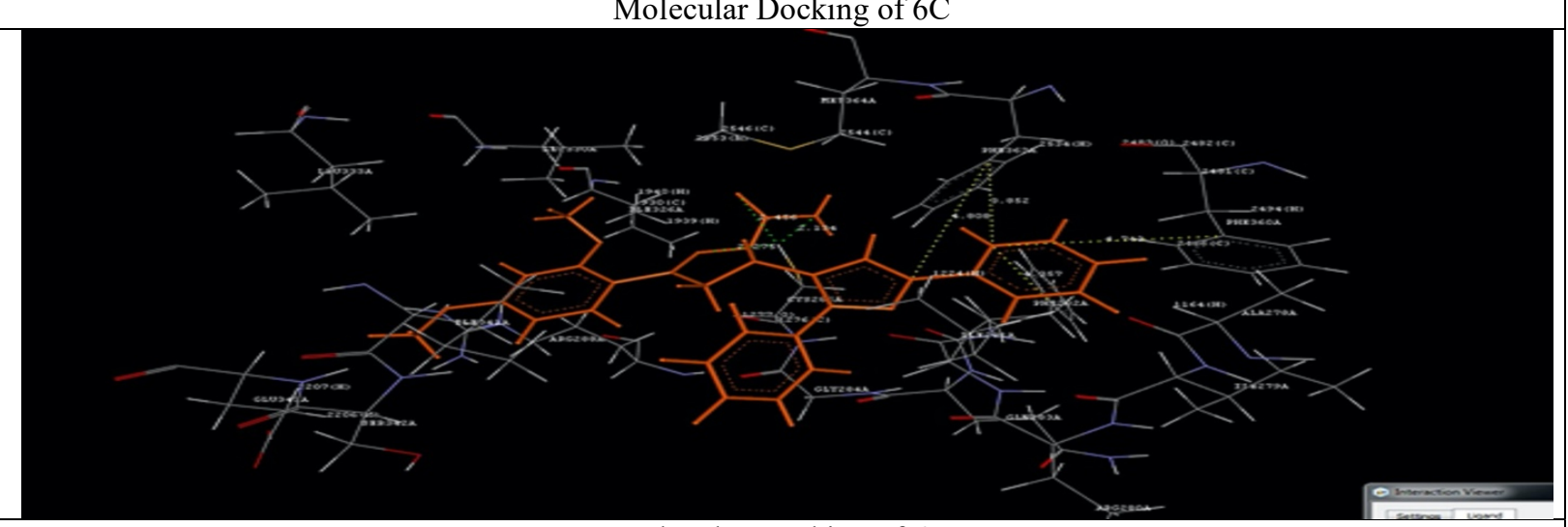

Molecular Docking of 6D

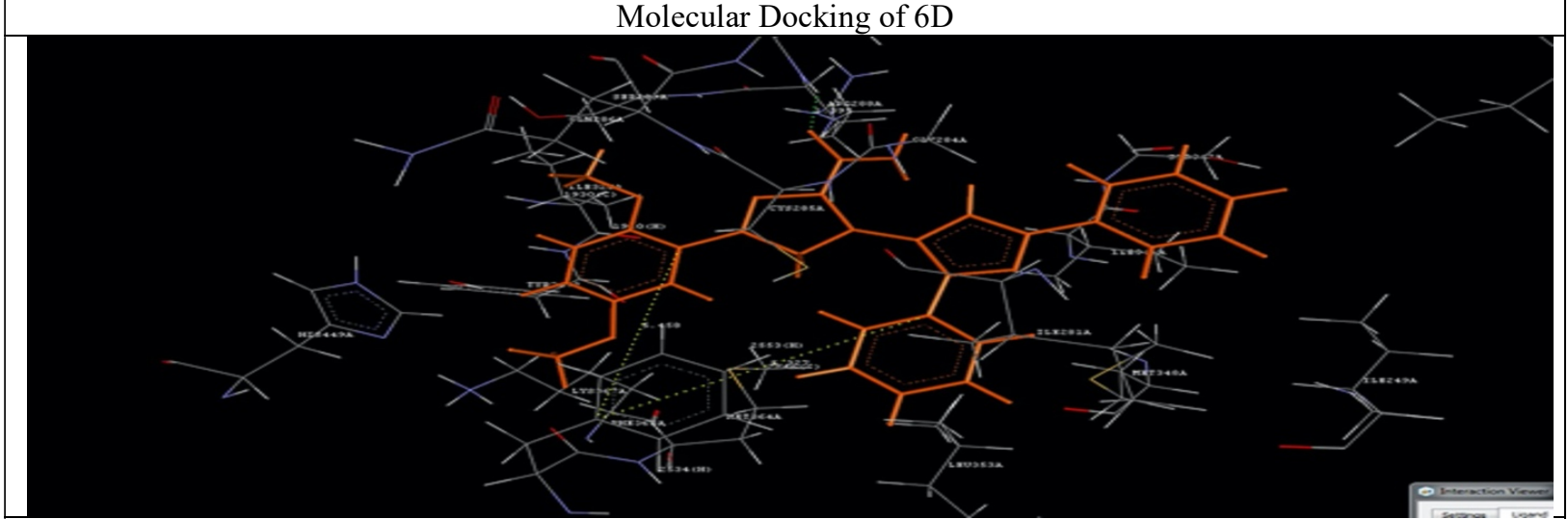

Molecular Docking of 6E

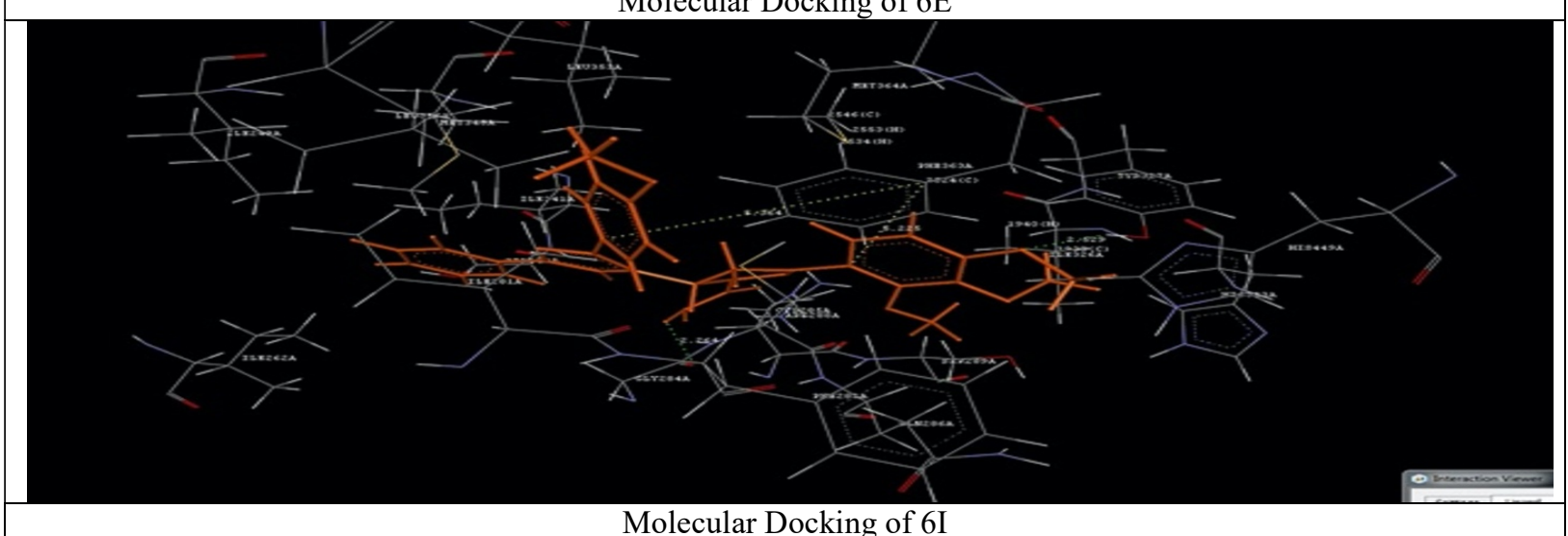

Fig.-2: Molecular Docking For Antidiabetic Activity

1409 
RASĀYAN J. Chem.

Vol. 13 | No. 3 |1401-1411| July - September | 2020

\section{Docking Study For Anti-diabetic Activity}

All synthesized derivatives have shown same binding mode for anti-diabetic activity $\mathbf{6 b}$ is the most active molecule showed important binding interactions like hydrogen bond interaction with ARG288, aromatic interaction withPHE287and hydrophobic interactions with CYS285, PHE287, ARG288, GLU291, ALA292, ILE296, ILE326, MET329, ILE341. 6c showed hydrogen bond interactions with SER342, GLU291 aromatic interaction with PHE287hydrophobic interactions with VLEU270, ARG280, ILE281, GLY284, PHE287, ARG288. 6d showed hydrogen bond interaction with CYS285, aromatic bond interaction with PHE282, PHE360, PHE363, and hydrophobic interactions with CYS285, ARG288, ILE326,LEU330,LEU333,ILE341,SER342, GLU343. 6e showed hydrogen bond interaction with ARG288, aromatic bond interaction with PHE363and hydrophobic interactions with CYS285, ARG288, ILE326, LEU330, LEU333, ILE341, SER342, GLU343. 6i showed hydrogen bond interactions with GLY284, TYR327 aromatic bond interaction with PHE363and hydrophobic interactions with CYS285, ARG288, ILE326, LEU330, LEU333, ILE341, LEU353, LEU356, MET364, HIS 449.

\section{CONCLUSION}

In summary, we have carried out the synthesis of novel series of $\mathrm{N}$-carboamyl pyrazolines, carried out their docking studies and screened for in vitro anti-inflammatory, antioxidant and antidiabetic activities. The pyrazolines are having potent biological activities. Compound $\mathbf{6 h}$ showed excellent antiinflammatory activity whereas compounds $\mathbf{6 a}, \mathbf{6 d}, \mathbf{6 g}$ and $\mathbf{6 j}$ showed excellent antioxidant activity for DPPH, compound $\mathbf{6} \mathbf{f}$ showed highest inhibition of NO free radical and compound $\mathbf{6 b}$ showed the highest inhibition for SOR free radical. On the other hand Compounds, $\mathbf{6 j}$ and $\mathbf{6 b}$ were found to be having the most potent antidiabetic activity among the series as compared to standard acarbose. The synthesized compounds showed good docking scores for anti-inflammatory as well as antidiabetic activity. Hence these newly synthesized N-carboamyl pyrazoline derivatives may be of great interest in the field of medicinal chemistry.

\section{ACKNOWLEDGMENT}

We are very thankful to the School of Chemical Sciences, PAH, Solapur University, Solapur for providing laboratory facility and thankful to Biocyte laboratory, Sangali for carrying out biological evaluations. We are also thankful to the instrumentation center of PAH Solapur university and Savitribai Phule, Pune University.

\section{REFERENCES}

1. M. Amir, H. Kumar, S.Khan, Bioorganic and Medicinal Chemistry Letters, 18, 918(2008), DOI: 10.1016/j.bmcl.2007.12.043

2. M.A. Ali, A.A. Siddiqui, M. Shaharyar, European Journal of Medicinal Chemistry, 42, 268(2007), DOI:10.1016/j.ejmech.2006.08.004

3. M. Idrees, S. Kola , N.J. Siddiqui , Rasayan Journal of Chemistry, 17, 1725(2019),DOI: 10.31788/RJC.2019.124567

4. E. Palaska , M. Aytemir , I.T. Uzbay, D. Erol, European Journal of Medicinal Chemistry, 36, 539 (2001), DOI:10.1016/s0223-5234(01)01243-0

5. D. Azarifar, M. Shaebanzadeh, Molecules, 7, 885(2002), DOI:10.3390/71200885

6. H. Dmytro, Z. Borys, V. Olexandr, Z. Lucjusz Z, Andrzej, L. Roman, European Journal of Medicinal Chemistry, 44, 1396(2009), DOI:10.1016/j.ejmech.2008.09.032

7. Z. Ozdemir, H. B. Kandilci, B. Gumusel, U. Calis, A. A. Bilgin, Archive der Pharmazie- Chemistry in Life Sciences, 341, 707(2008), DOI:10.1002/ardp.200800068

8. G. Turan-Zitouni, P. Chevallet, F.S. Kiliç, K. Erol, European Journal of Medicina Chemistrty, 35, 635 (2000), DOI: 10.1016/s0223-5234(00)00152-5

9. J. H. Ahn, H.M. Kim, S.H. Jung, S.K. Kung, K. R. Kim et al., Bioorganic and Medicinal Chemistry Letters, 14, 4461(2004), DOI:10.1016/j.bmcl.2004.06.046

10. T. Yaminilatha, D. Varalakshmi, G. Rajhita, International Journal of Pharmaceutical and Biological Science, 8, 374(2017), DOI:10.22376/ijpbs.2017.8.2

11. T. Irfan, M. Irfan, M. Abid, A. Azam, Rasayan Journal of Chemistry, 17, 2082(2019), DOI: $10.31788 /$ RJC.2019.1245320 
RASĀYAN J. Chem.

Vol. 13 | No. 3 |1401-1411| July - September | 2020

12. A. Mohd, A. Sazid, K. Somakala, Indian Journal of Chemistry, 55, 478(2016).

13. R.S. Joshi, P. G. Mandhane, S. D. Diwakar, S. K. Dabhad, C.H. Gill, Bioorganic and Medicinal Chemistry Lettres, 20, 3721(2009), DOI:10.1016/j.bmcl.2010.04.082

14. B. Ramesh, T. Sumana, E-Journal of Chemistry, 27, 514(2010), DOI:10.1155/2010/731675

15. V. Muralidharan, A. Deepti, S. Raja, International Journal of Pharmacy and Pharmaceutical Science, 10, 2(2018), DOI:10.22159/ijpps.2018v10i2.23772

16. D. H. Setiadi, G.A. Chass, L,L. Torday, A.Varro, Jornal of Molecular Structure, 620, 93(2003), DOI: $10.1016 / \mathrm{S} 0166-1280(02) 00604-8$

17. H.S. Vidyashree, J.B. Kalluraya, S.G. Kotathattu, Journal of Serbian Chemistry Society, 79, 1469(2014), DOI: 10.2298/JSC140109090J

18. M. Emayavaramban, N. Santhi, C. Gopi, C. Manivannan, A. Raguraman, International Letters of Chemistry, Physics and Astronomy, 14, 172(2013), DOI:10.18052/www.scipress.com

19. H. Israili, American Journal of Therapy, 18, 117(2011), DOI:10.1097/MJT.0b013e3181afbf51

20. H. Chi-Ting, H. Tusty-Jiuan H et. al, Bioorganic and Medicinal Chemistry Letters, 22, 3912(2012), DOI: $10.1016 /$ j.bmcl.2010.04.108

21. Y. Mizushima, M. Kobayashi, Journal of Pharmacy and Pharmacoology, 20, 169(1968), DOI: $10.1111 / j .2042-7158.1968 . t b 09718$

22. A. Kumar, B.G. Varadaraj, R.K. Singla, Bulletin of Faculty of Pharmacy, Cairo University, 51, 167 (2013), DOI:10.1016/j.bfopcu.2013.04.002

23. P. Bernfeld, P. Colowick, O.Kaplan, Academic Press; New York, NY, USA:149(1955), DOI: $10.1016 / 0076-6879(55) 01021-5$

24. www.rcsb.org

25. R.T. Nolte, G.B. WIsley, S. Westin, J.E. Cobb, M.H. Lamberet, R. Kurokawa, M.G Willson et. al, Nature, 395, 137(1998)

26. B.J. Orlando, M. G. Malkowsk, Acta Crystallografica Section F, 72, 772(2016), DOI: $10.1107 /$ S2053230X16014230

[RJC-5637/2019] 